\title{
KDM6A Gene Mutation
}

National Cancer Institute

\section{Source}

National Cancer Institute. KDM6A Gene Mutation. NCI Thesaurus. Code C150649.

A change in the nucleotide sequence of the KDM6A gene. 